\title{
Multiple endocrine adenomatosis (Type I) and familial hyperparathyroidism
}

\author{
R. T. JUNG \\ M.B., M.R.C.P. \\ M. DAVIE \\ M.B., M.R.C.P.
}

\author{
A. M. GRANT \\ M.B., M.R.C.P. \\ D. JENKINS \\ M.B., B.S.
}

\author{
T. M. Chalmers \\ M.D., F.R.C.P. \\ Addenbrooke's Hospital, Cambridge
}

\begin{abstract}
Summary
Hyperparathyroidism is the commonest presenting feature in multiple endocrine adenomatosis Type I (MEA Type I), the other manifestations may be delayed for many years or appear only in relatives. A family now diagnosed as MEA Type I, who was previously thought, in 1965, to have familial hyperparathyroidism due to chief cell hyperplasia is now described. The importance is stressed of family surveillance and long-term follow-up in all cases of primary hyperparathyroidism. Those tests that are essential in the long-term surveillance of the patients and their first degree relatives are discussed.
\end{abstract}

\section{Introduction}

In recent years there has been increasing awareness of the multiple endocrine adenomatosis (MEA) syndromes. In MEA Type I there is a grouping of tumours or hyperplasia of the parathyroids, pancreatic islets and pituitary, while MEA Type II is characterized by phaeochromocytoma, medullary thyroid carcinoma and parathyroid pathology. In MEA Type 1 hyperparathyroidism is the commonest presenting feature and other manifestations may be delayed for many years or appear only in relatives. The importance of long-term family surveillance is illustrated by the following case study which brings up to date the story of a family previously reported as an example of familial primary hyperparathyroidism due to chief cell hyperplasia (Adams et al., 1965; Peters et al., 1966).

\section{Case report}

A 40-year-old housewife $\left(\mathrm{II}_{3}\right.$ in Table 1) was admitted in April 1976 with acute myelo-monocytic leukaemia. Between 1960 and 1963 exploration of the neck had been performed on four occasions for chief

Correspondence: Dr R. T. Jung, Addenbrooke's Hospital, Cambridge. cell hyperplasia. Hypocalcaemia developed after the last of these operations and serum calcium contcentration was subsequently maintained within normal limits with two tablets of calcium and vitamin D BPC (1000 i.u.) per day. Between 1950 and 1954 she had had recurrent peptic ulceration. Studies in 1963 revealed no radiological evidence of pepHic ulcer but steatorrhoea was present. In 1974 faecal fat excretion was $30 \mathrm{~g} /$ day. A pentagastringtegt showed only mild hyperacidity. Fiberoscopy showeed normal antral mucosa: jejunal biopsy was ufirocessful. Barium studies showed no abnormality the stomach or duodenum: there was dilatation the small bowel with contrast flocculation. Afteroga gluten-free diet for one year faecal fat excretion whs unchanged.

Until acute leukaemia developed in 1976 the patient remained clinically well. By then, serum gastrin estimation was available and the concent㟽tion was found to be $>120 \mathrm{pmol} / 1$ (normal range, $<50 \mathrm{pmol} / \mathrm{l}$ ). Serum calcitonin was $3.8 \mu \mathrm{g} / \mathrm{l}$ (nofmal range, $<0.1 \mu \mathrm{g} / \mathrm{l}$ ). The pituitary fossa was of normal size. Plasma cortisol concentrations a urinary excretion of 5-HIAA and HMMA wege normal. Serum thyroxine was $46 \mathrm{nmol} / \mathrm{l}$ (normal range, $55-144 \mathrm{nmol} / \mathrm{l})$. Remission of the leukaemia was not achieved with chemotherapy and she died May 1976.

At post-mortem there was one remaining par thyroid gland which showed chief cell hyperplasi@. There was a small diffuse pituitary adenoma andra thyroid colloid cyst with no evidence of a medullate thyroid carcinoma. Five benign ulcers were presegt in the duodenum. Islet cell tumours were found of the pancreas, in one adjacent lymph node and at trgo sites in the first part of the duodenum. The adrenfal glands were normal. Leukaemic granulocytic pros liferation was present in the spleen, bone-marrow and bowel wall. 


\section{Family study}

The family tree is shown in Table 1 . Female patients $\mathrm{II}_{1} \mathrm{II}_{3}$ (described above), $\mathrm{II}_{5}$ and $\mathrm{III}_{1}$ have undergone parathyroidectomy for chief cell hyperplasia. On confirmation that patient $\mathrm{II}_{3}$ had MEA Type I a systemic biochemical survey of the family was carried out, including serum gastrin, calcitonin, parathyroid hormone, prolactin and thyroxine, fasting serum calcium, phosphate, glucose and insulin and urinary HMMA and 5-HIAA. The only new abnormality found was in patient $\mathrm{III}_{2}$ whose serum calcium was $2.7 \mathrm{mmol} / 1(10.8 \mathrm{mg} / 100 \mathrm{ml})$, albumin $46 \mathrm{~g} / \mathrm{l}$, phosphate $0.99 \mathrm{mmol} / 1(3.06 \mathrm{mg} /$ $100 \mathrm{ml}$ ), parathyroid hormone $2 \mathrm{ng} / \mathrm{ml}$ (normal range, $<0.9 \mathrm{mg} / \mathrm{ml}$ ) and calcitonin $0.32 \mu \mathrm{g} / 1$ (normal range, $<0 \cdot 1 \mu \mathrm{g} / \mathrm{l})$.

\section{Discussion}

MEA Type $I$ is inherited through an autosomal dominant gene with incomplete penetrance, and endocrine dysfunction can be variable with single or multiple involvement in any one family and at any age. The most frequent presenting feature is hypercalcaemia. In a recent series of 119 cases of primary hyperparathyroidism evidence of MEA was found in $17.5 \%$ and in $43 \%$ where two or more parathyroid glands were hyperplastic or adenomatous (Boey et al., 1975). In another series MEA was present in $18 \%$ of cases with chief cell hyperplasia (Castleman, Schantz and Roth, 1976).
In a recent study of the relatives of 100 consecutive patients with tumours or hyperplasia of the parathyroids, involvement of at least one additional family member was observed in ten index cases in the 91 of whom family data could be obtained $(11 \%)$. MEA Type I was found in three families and MEA Type II in two families (Jackson, Frome and Block, 1977).

Cases with features of both MEA Type I and Type II have been reported recently (Hansen et al., 1976). Patient $\mathrm{II}_{3}$ in the present series showed a raised calcitonin $(3.8 \mu \mathrm{g} / \mathrm{l})$ but as no medullary thyroid carcinoma was found this was probably secondary to the raised gastrin (Sizemore et al., 1973). The patient's nephew, III $_{2}$, also had a slightly raised calcitonin $(0.32 \mu \mathrm{g} / \mathrm{l})$ with a raised serum parathyroid hormone and calcium but normal gastrin. A pentagastrin-calcitonin stimulation test did not suggest medullary thyroid carcinoma, and the raised calcitonin might have been due to the raised calcium or parathyroid hormone (Sizemore and Go, 1975; Tashjian et al., 1970).

This case study emphasizes the importance of family surveillance and long-term follow-up in primary hyperparathyroidism. The authors suggest that all first degree relatives of patients with primary hyperparathyroidism, particularly when it is due to chief cell hyperplasia, should have a full clinical assessment and serum calcium and phosphate estimations. Further follow-up may be necessary in

TABle 1. Pedigree. Affected members of the family are shown as solid symbols, their age in years is given in parentheses

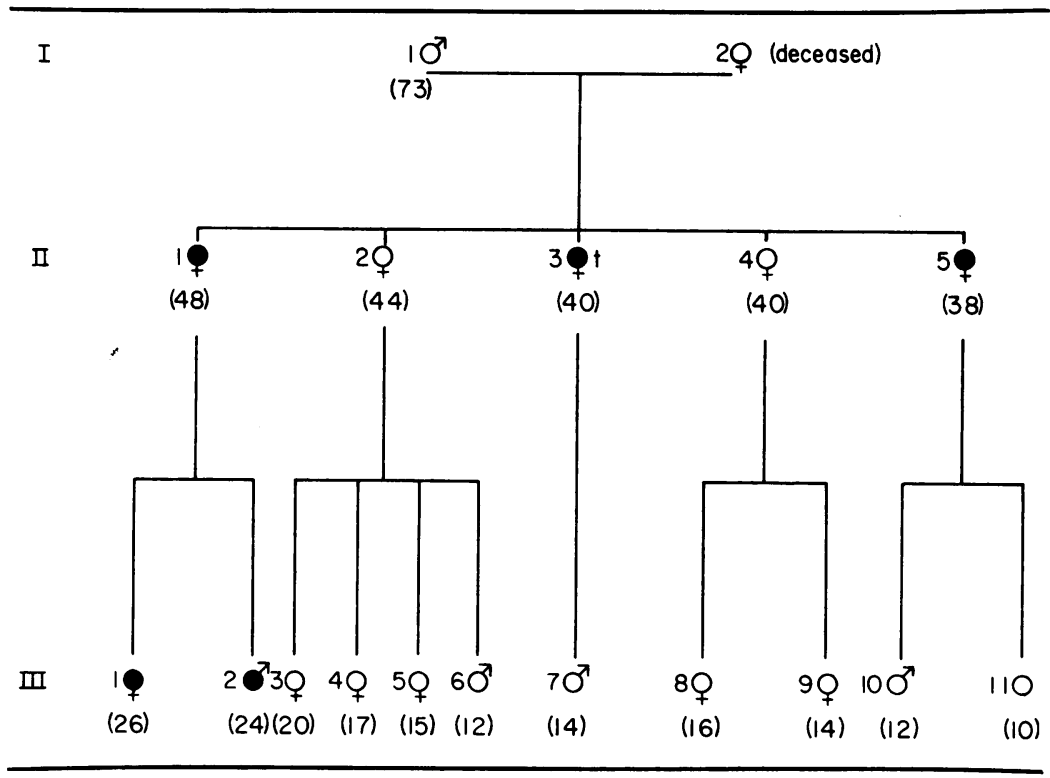


families particularly where the initial studies reveal involvement of more than one member. The cost of detailed endocrine studies, such as those reported in this article, at present precludes their use except where there are definite clinical indications.

\section{Acknowledgments}

We thank the Regional Hormone Assay Service of Addenbrooke's Hospital and the Supraregional Assay Service of Hammersmith Hospital (especially Dr Carole Hillyard) for the provision of the hormone assays.

\section{References}

Adams, P.H., Chalmers, T.M., Peters, N., Rack, J.H. \& Truscott, B. MCN. (1965) Primary chief cell hyperplasia of the parathyroid glands. Annals of Internal Medicine, 63, 454.

Boey, J.H., Cooke, T.J.C., Gilbert, J.H., Sweeney, E.C. \& TAYLOR, S. (1975) Occurrence of other endocrine tumours in primary hyperparathyroidism. Lancet, ii, 781.

Castleman, B., Schantz, A. \& Roth, S.I. (1976) Parathyroid hyperplasia in 'primary hyperparathyroidism. A review of 85 cases. Cancer, 38, 1668.
Hansen, O.P., Hansen, M., Hansen, H.H. \& Rose, B. (197 Multiple endocrine adenomatosis of mixed type. Acro medica scandinavica, 200, 327.

Jackson, C.E., Frome, B. \& Block, M.A. (1977) The spe trum of hereditary hyperparathyroidism. In: Proceeding of 6th Parathyroid Conference, Vancouver, Canada. Jure 1977 (in press).

Peters, N., Chalmers, T.M., Truscott, B.McN., Rach. J.H. \& Adams, P.M. (1966) Familial hyperparathyroidisn Postgraduate Medical Journal, 42, 228.

Sizemore, G.W. \& Go, V.L.W. (1975) Stimulation tests fờ diagnosis of medullary thyroid carcinoma. Proceedings. Mayo Clinic, 50, 53.

Sizemore, G.W., Go, V.L.W., Kaplan, E.L., Sanjed BaCher, L.J., Holter-Muller, K.H. \& ARnaud, C.ゆి (1973) Relations of calcitonin and gastrin in Zollingep Ellison syndrome and medullary carcinoma of the thyroles New England Journal of Medicine, 288, 641.

Tashian, A.H., Howland, B.G., Melvin, K.E.W. \& Hil C.S. (1970) Immunoassay of human calcitonin. Clinic measurement, relation to serum calcium and studies patients with medullary carcinoma. New England Journad of Medicine, 283, 890. 